\title{
Prohepcidin Levels in Refractory Anaemia Caused by Lead Poisoning
}

\author{
Jayantha Arnold ${ }^{a} \quad$ Mark Busbridge $^{c} \quad$ Arvind Sangwaiya $^{a}$ \\ Bharati Bhatkal $^{\mathrm{a}}$ Parth Paskaran $^{\mathrm{a}}$ Arabinda Pal $^{\mathrm{a}}$ \\ Frank Geoghegan $^{\text {b }}$ Terence Kealey $^{d}$ \\ Departments of a Gastroenterology and ${ }^{\mathrm{b}} \mathrm{Chemical}$ Pathology, Ealing Hospital, \\ Southall, 'Department of Clinical Chemistry, Hammersmith Hospital, London, and \\ dPostgraduate Medical School, University of Buckingham, Buckingham, UK
}

\section{Key Words}

Hepcidin · Prohepcidin · Lead poisoning · Porphyrins · Abdominal pain · Sideroblastic anaemia

\begin{abstract}
Recent research evidence suggests a central role for hepcidin in iron homeostasis. Hepcidin is a hormone synthesized in the liver. Hepcidin is also thought to play a vital role in the pathogenic mechanism of anaemia in patients with inflammation or chronic disease. A 38-year-old female who presented with recurrent abdominal pain was found to have raised urinary porphyrins and a blood lead level of $779 \mu \mathrm{g} / \mathrm{l}$. Her haemoglobin level was $8.3 \mathrm{~g} / \mathrm{dl}$. Her MCV was normal. Serum ferritin, B12 and folate were normal. Her serum prohepcidin level was $2,489 \mathrm{ng} / \mathrm{ml}$ (normal $<450 \mathrm{ng} / \mathrm{ml}$ ). To our knowledge, this is the first report of raised prohepcidin levels in a patient with anaemia of chronic disease resulting from lead poisoning.
\end{abstract}

\section{Introduction}

Iron is absorbed mainly in the duodenal mucosa. There is no mechanism to shed iron in humans other than with natural blood loss during menstruation. Therefore iron homeostasis is maintained by regulating iron absorption. Influx and efflux of iron in duodenal enterocytes is regulated by ferroportin. Ferroportin is a hepcidin binding protein expressed in duodenal enterocytes. Hepcidin is a peptide synthesised in the liver and is the main regulator of iron homeostasis [1-3]. The hepcidin gene is principally expressed in hepatocytes and to a lesser extent in neutrophils and macrophages [4-7]. 
When total body iron stores are low with reduced circulating serum iron levels, the iron sensor will signal a reduction in hepcidin synthesis. The iron sensoring mechanism is thought to be a complex process, the details of which have not been fully elucidated as yet. The resultant reduction in circulating hepcidin concentrations will modulate ferroportin activity and lead to greater uptake and export of iron in duodenal enterocytes. Therefore a direct dynamic correlation exists between serum iron and hepcidin synthesis as a feedback mechanism to reduce iron entry or accelerate entry reflecting the changing iron requirements. Essentially hepcidin is a hormone negatively regulating iron absorption. In addition to serum iron, an erythropoietic signal also influences hepcidin synthesis, but the specific mediator has not been described as yet. High erythropoietic activity appears to suppress hepcidin synthesis as a feedback mechanism.

The hepcidin-ferroportin interaction in duodenal enterocytes is the rate-limiting step for iron export from duodenal enterocytes which in turn influences iron uptake into the enterocyte involving the DMT1 (divalent metal transporter protein 1) from the intestinal lumen [8].

Hepcidin plays a central role in the pathogenesis of hereditary haemochromatosis [6, 8-10] by failing to suppress iron uptake and export from duodenal enterocytes leading to iron overload, the hallmark of this disease.

Haemojuvelin mutation, which is rare, causes severe early onset juvenile haemochromatosis. Haemojuvelin encoded by the gene HFE2 is a critical upstream regulator of hepcidin expression [11].

In patients with iron deficiency, hepcidin synthesis is suppressed and serum haemojuvelin has been found to be elevated [11]. In addition to haemojuvelin, another signal protein called bone morphogenic protein (BMP) also influences hepcidin synthesis and is thought to be the central regulator affecting hepcidin synthesis responding to changes in serum iron $[8,12]$.

Hepcidin synthesis is reduced in transferrin receptor 2 haemochromatosis, another rare form of haemochromatosis, which is independent of mutations in HFE gene [13]. High hepcidin levels are also thought to account for anaemia of chronic disease and anaemia in patients with chronic renal failure.

We describe a patient with lead poisoning in whom iron studies were undertaken. As one of several investigations, she had serum prohepcidin (the hepcidin prohormone) levels measured.

\section{Case Description}

A 38-year-old female was referred to the outpatient clinic for recurrent severe abdominal pain. This was not associated with any vomiting or diarrhoea. She had been unwell for two years and had been seen in several gastroenterology clinics with unexplained abdominal pain and anaemia. She did not have any drug allergy. She was a married housewife with children. Clinical examination was unremarkable.

The patient had exhaustive gastrointestinal investigations including gastroscopy, colonoscopy, barium follow through and CT scan of the abdomen which were all normal. Urinary porphyrins were measured to investigate possible porphyria as the cause of abdominal pain. The urinary porphyrin results raised the possibility of lead poisoning and this was confirmed by two separate blood samples taken for serum lead level.

Her haemoglobin was $8.3 \mathrm{~g} / \mathrm{dl}(12-16 \mathrm{~g} / \mathrm{dl})$, MCV $91 \mathrm{fl}(82-100 \mathrm{fl})$. Her white cell count and platelet count were both normal. Thyroid function tests were normal as well. Serum iron was $14 \mu \mathrm{mol} / \mathrm{l}(6.6-30$ 
$\mu \mathrm{mol} / \mathrm{l})$, TIBC $68 \mu \mathrm{mol} / \mathrm{l}(45-72 \mu \mathrm{mol} / \mathrm{l})$, ferritin was $109 \mathrm{ng} / \mathrm{l}$ (4.6-204 ng/l). Haemoglobin electrophoresis showed normal haemoglobin electrophoretic pattern.

Her ESR was $28 \mathrm{~mm} / \mathrm{h}$ and C-reactive protein was $<7.0 \mathrm{mg} / \mathrm{l}$ (normal $<10 \mathrm{mg} / \mathrm{l}$ ). Liver function tests were normal. Gut hormone profile was within normal limits. Serum immunoglobulin levels were normal. $24 \mathrm{~h}$ urinary catecholamines were normal. Tumour markers including CEA, Ca 125 and Ca 199 were normal.

Blood porphyrins showed elevated erythrocyte zinc protoporphyrin at $1,731 \mathrm{nmol} / \mathrm{l}$ and erythrocyte free protoporphyrin at $748 \mathrm{nmol} / \mathrm{l}$. Urinary porphyrin showed raised total coproporphyrin I and II level at $20,415 \mathrm{nmol} / \mathrm{l}(<115 \mathrm{nmol} / \mathrm{l})$. Coproporphyrin-I level was 19,940 nmol/l. Erythrocyte 5-nucleotidase level was $5.6 \mathrm{IU} / \mathrm{l}(0-9 \mathrm{IU} / \mathrm{l})$.

Her serum lead level was $779 \mu \mathrm{g} / \mathrm{l}($ normal $<100 \mu \mathrm{g} / \mathrm{l})$ and on repeat testing was found to be raised at $707 \mu \mathrm{g} / \mathrm{l}$. Serum folate and B12 levels were normal. Review of blood film confirmed basophilic stippling in red cells.

A blood sample was taken for the measurement of hepcidin prohormone by ELISA method (DRG Diagnostics, Immunodiagnostic Systems Ltd, Bolton Tyne and Wear, UK). The sample was stored at $80^{\circ} \mathrm{C}$ and allowed to return to room temperature before analysis and the result was $2,489 \mathrm{ng} / \mathrm{ml}$. In healthy volunteers, prohepcidin levels have previously been reported to be less than $450 \mathrm{ng} / \mathrm{ml}[9,14]$.

The source of lead poisoning was not identified. She had chelation therapy with penicillamine and her lead levels returned to normal.

\section{Discussion}

Hepcidin is an acute phase protein and its synthesis will be increased in inflammatory diseases as a result of stimulation by interleukin- $6[15,16]$. Our patient did not have any evidence of concurrent inflammation or infection when her hepcidin was measured.

Plasma hepcidin assay, as opposed to prohepcidin assay, is not commercially available, although a semiquantitative ProteinChip System has recently been described [17].

There is no reason to suspect that a direct linear relationship would not exist in vivo between the prohormone prohepcidin and hepcidin. A raised prohepcin must indicate that her hepcidin level, if it was possible to measure it, would have been high too. Prohepcidin is a 60 aminoacid peptide cleaved by proteases to form the biologically active 25-peptide hepcidin [18]. Hepcidin levels are known to be increased in patients with chronic inflammation. This is thought to be responsible for trapping iron in macrophages, resulting in reduced serum iron levels. This leads to anaemia of chronic disease [19]. Refractory anaemia caused by lead poisoning is referred to as sideroblastic anaemia. Sideroblastic anaemias are a heterogenous group of inherited or acquired disorders characterised by defective haemoglobin synthesis within erythroblasts leading to ineffective erythropoiesis.

To our knowledge, this is the first report describing raised prohepcidin levels in a patient with refractory anaemia from lead poisoning. It is likely that lead toxicity resulted in accelerated synthesis of hepcidin in hepatocytes or macrophages which in turn caused refractory anaemia. This is thought to be due to iron trapping in macrophages and failure of iron uptake in erythroid precursor cells in the bone marrow.

In anaemia of chronic disease, to some extent, zinc functions as an alternative protoporphyrin ligand by incorporating into protoporphyrin during haem synthesis. In anaemia of chronic disease, this can lead to increased zinc protoporphyrin levels [20]. Therefore another mechanism in the pathogenesis of anaemia in lead poisoning could be 
disrupted haem synthesis involving defective iron incorporation into haem, a process that may be mediated by hepcidin. 


\section{References}

1 Gehrke SG, Kulaksiz H, Herrmann T, et al: Expression of hepcidin in hereditary haemochromatosis: evidence for a regulation in response to the serum transferrin saturation and to non transferrin bound iron. Blood 2003;102:371-376.

-2 Park CH, Valore EV, Waring AJ, et al: Hepcidin, a urinary antimicrobial peptide synthesized in the liver. J Biol Chem 2001;276:7806-7810.

-3 Krause A, Neitz S, Magert HJ, et al: LEAP-1, a novel highly disulfide-bonded human peptide, exhibits antimicrobial activity. FEBS Lett 2000;480:147-150.

-4 Pigeon C, Ilyin G, Courselaud B, et al: A new mouse liver-specific gene, encoding a protein homologous to human antimicrobial peptide hepcidin, is overexpressed during iron overload. J Biol Chem 2001;276:7811-7819.

5 Zhang A, Xiong S, Tsukamoto H, Enns CA: Localisation of iron metabolism related mRNAs in rat liver indicate that HFE is expressed predominantly in hepatocytes. Blood 2004;103:1509-1514.

6 Pietrangelo A: Hemochromatosis: an endocrine liver disease. Hepatology 2007;46:1291-1301.

7 Peysonnnaux C, Zinkernagel AS, Datta V, et al: TLR4-dependent hepcidin expression by myeloid cells in response to bacterial pathogens. Blood 2006;107:3727-3732.

8 Ganz T: Molecular control of iron transport. J Am Soc Nephrol 2007;18:394-400.

-9 Kulaksiz H, Gehrke SG, Janetzko A, et al: Pro-hepcidin: expression and cell specific localisation in the liver and its regulation in hereditary haemochromatosis, chronic renal insufficiency, and renal anaemia. Gut 2004;53:735-743.

10 Bridle KR, Fraser DM, Wilkins SJ, et al: Disrupted hepcidin regulation in HFE associated haemochromatosis and the liver as a regulator of body iron homeostasis. Lancet 2003;361:669-673.

-11 Zhang AS, Anderson S, Meyers KR, et al: Evidence that inhibition of hemojuvelin shedding in response to iron is mediated through neogenin. J Biol Chem 2007;282:12547-12556.

-12 Truksa J, Pen H, Lee P, Beutler E: Different regulatory elements are required for response of hepcidin to interleukin 6 and bone morphogenetic proteins 4 and 9 . Br J Haematol 2007;139:138-147.

13 Nemeth E, Roetto A, Garozo G, et al: Hepcidin is decreased in TFR2 hemochromatosis. Blood 2005;105:1803-1806.

14 Roe MA, Spinks C, Heath AL, et al: Serum prohepcidin concentration: no association with iron absorption in healthy men; and no relationship with iron status in men carrying HFE mutations, hereditary haemochromatosis patients undergoing phlebotomy treatment, or pregnant women. Br J Nutr 2007;97:544549 .

15 Walsh JB: Assessing iron status: beyond serum ferritin and transferrin saturation. Clin J Am Soc Nephrol 2006;Suppl 1:S1-S8.

-16 Nemeth E, Valore EV, Territo M, et al: Hepcidin, a putative mediator of anaemia of inflammation, is a type II acute phase protein. Blood 2003;101:2461-2463.

17 Tomosugi N, Kawabata H, Wakatabe R, et al: Detection of serum hepcidin in renal failure and inflammation by using ProteinChip system. Blood 2006;108:1381-1387.

18 Valore EV, Ganz T: Posttranslational processing of hepcidin in human hepatocytes is mediated by the prohormone convertase furin. Blood Cells Mol Dis 2008;40:132-138.

19 Ganz T: Molecular pathogenesis of anemia of chronic disease. Pediatr Blood Cancer 2006;46:554-557.

20 Hastka J, Lasserre JJ, Schwarzbeck A, et al: Zinc protoporphyrin in anemia of chronic disorders. Blood 1993;81:1200-1204. 